Jurnal Penyuluhan, Maret 2010 Vol. 6 No.1

\title{
Partisipasi Petani dalam Pembangunan Pedesaan di Kabupaten Konawe
}

\section{Farmers' Partisipation in Developing Rurals At Regency of Konawe}

\author{
Rayuddin ${ }^{1}$, Tambaru $\mathrm{Zau}^{1}$, dan Ramli $^{1}$ \\ ${ }^{1}$ Dosen Universitas Lakidende Konawe Sultra
}

\begin{abstract}
This study is proposed in answering to the question of "What types of partisipation do farmers give in developing Rurals Areas in Regency of Konawe". This study was conducted in the rural areas of farmers who have joined in farmer groups, included outlying rural areas and swasembada rural areas in the Regency of Konawe. Technique of choosing samples was carried out by "cluster purposive sampling", i.e., firstly, population is grouped based on regions/rural areas, then 5 respondents are chosen purposively from every farmer (member of farmer group) who have been choosen from 10 rural areas. Finally, 50 samples of respondents are chosen (farmers who are members of farmer group). Data collection was undertaken by three methods, they are: (1) indepth observation, (2) indepth interview, and (3) focus group discussion (FGD). Questions on the implementation of rural area development in list of questionnaire forms are formulated into three stages of categories; they are full participation $(P P)$ with score 3, partly/moderate participation $(P S)$ with score 2, and less participation with score 1. The result shows that type of farmers participations mostly are categorized into partly/moderate participation, that is 72 percent, and the rest, respectively, are 10.66 percent for full participation and 17,34 percent for less participation. Types of participations in developing rural areas in Regency of Konawe were carried out through three models of participation approach, i.e., farmer participation in developing means and infrastructure of rural areas, participation in strengthening sosio-economical rural areas, and participation in improving output of rural area farming. In conclusion, opportunity, competence, and willingness of farmers to take part in developing rural areas are very low because of the barrier of social system from elite groups in rural areas, as well as it is mostly influenced by the dependence of government program realization, as well as social mobilization which is most familiar in rural communities. Therefore, farmers are given few opportunities actively and really in developing their rural areas.
\end{abstract}

Keywords: farmer participation, rural development, social and community prosperity

\section{Pendahuluan}

Pembangunan yang partisipatif (participatory Development) merupakan proses yang melibatkan masyarakat secara aktif dalam seluruh keputusan subtansial yang berkenaan dengan kehidupan masyarakat dipedesaan. Dalam bidang kesejahteraan sosial, konsep partisipasi dapat dimaknai sebagai upaya melawan ketersingkiran (marginality) sehingga dalam partisipasi masyarakat, siapapun dapat memainkan peranan secara aktif, memiliki control terhadap kehidupannya sendiri, mengambil peran dalam kegiatan dimasyarakat, serta menjadi lebih terlibat dalam pembangunan.

Secara umum, sisi positif dari partisipasi adalah program yang dijalankan akan lebih respon terhadap kebutuhan dasar yang sesungguhnya, sebagai suatu cara penting untuk menjamin keberlanjutan program pembangunan kesejahteraan sosial masyarakat, akan lebih efisien karena membantu mengidentifikasi strategi dan teknik yang lebih tepat, serta meringankan beban program dari sisi dana, tenaga maupun material.

\footnotetext{
${ }^{1}$ Korespondensi penulis: 081317350011
} 
Namun sisi negatif dari partisipasi tersebut, akan melonggarkan kewenangan pihak pemangku kebijakan program sehingga akuntabilitas pemangku program sulit diukur, proses pembuatan keputusan menjadi lambat, demikian pula pelaksanaannya, serta bentuk program juga akan berbeda-beda karena masyarakat yang beragam. Disamping itu, program juga berpeluang untuk diselewengkan oleh pihak tertentu untuk kepentingan kelompoknya sendiri (Syahyuti, 2006).

Keberhasilan pembangunan daerah dan nasional sangat ditentukan oleh tingkat partisipasi masyarakat khususnya petani yang sebagian besar berada di pedesaan. Hampir 80 persen penduduk Kabupaten Konawe hidup di pedesaan yang jauh dari pusat-pusat administrasi pembangunan yang umumnya berada di kota-kota kabupaten sehingga tidaklah mengherankan jika masih banyak rakyat yang belum tersentuh kesempatan untuk berpartisipasi dalam pembangunan termasuk menikmati hasil pembangunan (Slamet, 2003). Pertanyaan-pertanyaan mengenai partisipasi masyarakat, biasanya mengenai keefektifan program-program pemerintah yang penting dalam sector pedesaan, keluarga berencana, pembangunan desa, dan kesejahteraan sosialekonomi masyarakat desa.

Konawe merupakan salah satu kabupaten yang berada dalam wilayah propinsi Sulawesi Tenggara. Potensi sumber daya alam dan penduduk Kabupaten Konawe sangat ditunjang oleh pembangunan di sektor pertanian. Hal ini dikarenakan, sebagian besar penduduk Kabupaten Konawe bermata pencaharian sebagai petani dan memberi kontribusi Product Domestic Regional Bruto (PDRB) Kabupaten Konawe sebesar 46,70 persen berasal dari sector pertanian (Biro Pusat Statistik, 2005). Kondisi geografis dan sumber daya alam yang dimiliki wilayah tersebut dapat menunjang gerak dan laju pertumbuhan ekonomi, pembangunan pertanian dan kesejahteraan sosial masyarakat di Kabupaten Konawe.

Perubahan paradigma pembangunan masa lalu yang dominan sifatnya top down approach telah memandulkan partisipasi masyarakat yang sifatnya asli atau genuine, sehingga mengaburkan arti dan makna partisipasi masyarakat petani dalam pembangunan (Adi, 2003). Di sisi lain, kurang tepatnya upaya mendekatkan kegiatankegiatan pembangunan pertanian pada wilayah-wilayah pedesaan yang direncanakan secara sentralistik belum mengakomodir kebutuhan masyarakat petani di pedesaan yang senantiasa selalu diarahkan oleh pemerintah desa dan lebih mempunyai kecenderungan memunculkan partisipasi semu masyarakat petani dalam kegiatan pembangunan bahkan memberi kesan petani tidak mandiri dan sangat tergantung dengan bantuan program yang dilaksanakan oleh Pemerintah Pusat maupun daerah.

Adanya partisipasi semu sangat tidak dikehendaki dalam kegiatan pembangunan karena partisipasi semacam itu tidak akan memberi arti bagi masyarakat petani dalam memanfaatkan hasil pembangunan dan berarti pula bahwa masyarakat petani di pedesaan tidak dapat diberdayakan dalam meningkatkan taraf hidup dan kesejahteraannya (Bappenas, 2003). Sebaliknya apabila bentuk partisipasi masyarakat petani sudah menunjukkan perubahan terhadap bentuk partisipasi sesungguhnya dalam pembangunan pedesaan yang dapat dibuktikan dengan hasil kajian sosial ekonomi pertanian melalui perolehan data kualitatif-deskriptif dari aktivitas dan perilaku masyarakat petani secara representative terhadap pembangunan, maka dapat dikatakan bahwa program pembangunan dan partisipasi petani sangat berkaitan erat keduanya terhadap manfaat pembangunan, selanjutnya jika kaitan ini tidak jelas maka sulitlah membangkitkan partisipasi masyarakat petani dalam perencanaan program pemberdayaan masyarakat petani dalam pembangunan pedesaan.

Kenyataan yang terjadi sekarang menunjukkan adanya persepsi masyarakat terhadap aktivitas pelaksanaan program pembangunan yang keliru menggunakan istilah partisipasi dalam pembangunan. Sebenarnya bisa saja dalam pogram pembangunan 
tertentu tidak perlu yang memanfaatkan hasil pembangunan harus ikut menyumbang secara langsung bagi pembangunan. Hal ini dikarenakan, dengan ikut memanfaatkan hasil pembangunan maka dapat dikatakan telah ikut mensukseskan pembangunan pertanian di pedesaan. Dengan demikian, partisipasi dalam pembangunan di pedesaaan dapat ditunjukkan dengan berbagai macam perilaku masyarakat petani di pedesaan dengan ikut memberi input proses pembangunan, menerima atas input tersebut, dan ikut menikmati hasilnya atau salah satu kriteria saja yang dialami oleh petani terhadap pembangunan. Kemanfaatan pembangunan biasa bersifat dekat dan dapat pula bersifat jauh, hal itu tidak hanya dalam arti jarak dan atau waktu terutama dalam arti persepsi masyarakat terhadap pembangunan itu sendiri (Slamet, 2003).

Sebagai ilustrasi salah satu bentuk partispasi masyarakat dalam pembangunan yaitu petani yang memanfaatkan dengan efisien air irigasi yang berasal dari pembangunan Bendungan Ameroro sebagai sumber air irigasi terbesar di wilayah Kabupaten Konawe dapat dikatakan telah ikut berpartisipasi, sebab bila petani tidak mau memanfaatkan maka pembangunan bendungan itu tidak dapat dikatakan tidak berhasil. Belum adanya kejelasan mengenai bentuk partisipasi petani dalam pembangunan pedesaan maka diperlukan adanya studi dan pengkajian yang mendalam serta berkesinambungan agar masalah partisipasi dan pemberdayaan masyarakat petani yang dapat meningkatkan kesejahteraan hidupnya di pedesaan dapat dideskripsikan secara tepat dalam upaya menempatkan posisi, peran dan keikutsertaan petani sebagai stakeholders sehingga pembangunan pedesaan dapat tumbuh dan berkembang secara berkesinambungan ke arah kemandirian masyarakat (Sumardjo, Saharuddin, 2004).

Penelitian ini bertujuan untuk mengetahui bentuk dan keterkaitan partisipasi petani terhadap pembangunan dan kesejahteraan sosial masyarakat yang telah direncanakan dan diprogramkan oleh Pemerintah Daerah maupun Pusat pada suatu wilayah pedesaan di Kabupaten Konawe Propinsi Sulawesi Tenggara. Secara proporsional partisipasi dalam pembangunan pedesaan lebih ditekankan pada keterlibatan "local people" sampai pada bentuk aksi kolektif masyarakat petani yang menyusun dan mengimplementasikan rencana mereka sendiri. Hasil dari penelitian ini diharapkan dapat digunakan untuk menyusun dasar-dasar perbaikan program pemberdayaan masyarakat petani dan kesejahteraan sosial masyarakat dipedesaan untuk menggerakkan partisipasi petani dalam pembangunan pedesaan. Penelitian ini juga berguna dalam perolehan informasi yang akurat mengenai keragaman bentuk kebutuhan pembangunan di pedesaan yang berbasis pada masyarakat lokal setempat (komunitas) guna menjamin keberlanjutan mata pencaharian hidup masyarakat di pedesaan.

\section{Metodologi Penelitian}

Penelitian ini dilaksanakan pada sepuluh desa sampel yang termasuk kategori desa tertinggal dan kategori desa swasembada dari 30 Kecamatan dan 245 desa/kelurahan di Kabupaten Konawe, yang mempunyai petani anggota kelompoktani yang mempunyai peran dalam pertumbuhan dan pergerakan sosial ekonomi masyarakat di pedesaan. Selanjutnya ditentukan sebaran wilayah desa sampel dari kecamatan yang terwakili sebagai objek penelitian partisipasi petani dalam pembangunan pedesaan di wilayah Kabupaten Konawe. Teknik penentuan sampel dilakukan secara "cluster purposive sampling" yaitu populasi dikelompokkan berdasarkan wilayah/desa, kemudian masing-masing petani anggota kelompoktani yang terwakili pada 10 wilayah desa dengan kategori desa tertinggal, dan desa swasembada yang terpilih ditentukan masing-masing 5 petani sampel secara sengaja (purposive) dalam setiap desa sampel sebagai responden sampel sehingga total keseluruhan sampel sebanyak 50 sampel. Jenis data yang digunakan dalam penelitian 
ini terdiri dari data primer dan data sekunder. Pengumpulan data primer dilakukan dengan metode indepth observation (pengamatan mendalam) untuk mendeskripsikan bentuk partisipasi petani dalam memberikan input dan memanfaatkan hasil pembangunan. Untuk memahami lebih dalam keterkaitan partisipasi masyarakat petani terhadap pembangunan pedesaan, pendekatannya dilakukan dengan metode indepth interview (wawancara mendalam) yang dilengkapi dengan kuisioner (Lipton \& Moore, 1980). Sumber data primer juga dikumpulkan melalui pelaksanaan focus group discution (FGD) terhadap informan kunci dalam masyarakat desa (tokoh masyarakat, tokoh adat, dan petugas sosial) untuk menggali lebih jauh pandangan, aktivitas, dan keterlibatan petani anggota kelompoktani serta aspek pemberdayaan masyarakat pada setiap program pembangunan pedesaan yang telah dilaksanakan dalam komunitas masyarakat setempat. Data skunder diperoleh dari pencatatan data yang telah tersedia di kantor-kantor pemerintah daerah Kabupaten Konawe.

Tipologi partisipasi yang akan diukur sebagai indikator dalam penelitian partisipasi petani dalam pembangunan pedesaan, didasarkan pada pengklasifikasian para ahli mengenai partisipasi (Sahyudi, 2006), yang berturut-turut semakin dekat pada bentukbentuk yang ideal, yaitu: (1) partisipasi pasif atau manipulatif merupakan bentuk partisipasi yang paling lemah, (2) partisipatif informatif, yakni masyarakat hanya menjawab pertanyaan-pertanyaan untuk proyek, namun tidak berkesempatan untuk terlibat dan mempengaruhi proses keputusan, (3) partisipasi konsultatif, yakni masyarakat berpartisipasi dengan cara berkonsultasi, sedangkan orang luar mendengarkan serta menganalisa masalah dan pemecahannya, (4) partisipasi insentif, yakni masyarakat memberikan korbanan dan jasa untuk memperoleh imbalan insentif berupa upah, (5) partisipasi fungsional, yakni masyarakat membentuk kelompok sebagai bagian proyek, setelah ada keputusan-keputusan utama yang disepakati, (6) partisipasi interaktif, yakni masyarakat berperan dalam proses analisis untuk perencanaan kegiatan dan pembentukan atau penguatan kelembagaan, dan (7) kemandirian (self mobilization), yakni masyarakat mengambil inisiatif sendiri secara bebas atau tidak dipengaruhi oleh pihak luar untuk merubah sistem atau nilai-nilai yang mereka junjung.

Dengan berbagai indikator partisipasi tersebut, dikembangkan model partisipasi petani dalam pembangunan pedesaan, dengan pernyataan dan pertanyaan yang dijabarkan dalam bentuk daftar kuesioner yang diformulasikan dalam tiga kategori partisipasi yaitu partisipasi penuh (PP) dengan skor 3, partisipasi setengah atau sedang (PS) dengan skor 2, dan partisipasi kurang (PK) dengan skor 1, terhadap pelaksanaan pembangunan pedesaan yang terkait dengan kesejahteraan sosial masyarakat petani. Selanjutnya data hasil wawancara dengan menggunakan kuisioner tersebut diolah dan ditabulasi berdasarkan nilai rating skor dan persentase partisipasi yang kemudian dianalisis secara deskriptif kualitatif, untuk menginterpretasikan dan menggambarkan wujud bentuk-bentuk partisipasi petani dalam pembangunan pedesaan di Kabupaten Konawe yang terkait dengan masalah kesejahteraan sosial masyarakat petani yang akan diteliti.

\section{Hasil Dan Pembahasan}

Identitas Petani Responden

Identitas petani anggota kelompoktani responden menggambarkan keadaan petani berdasarkan kondisi sosial ekonominya yang mempengaruhi motivasi dan bentuk partisipasi yang akan dilakukan dalam pelaksanaan pembangunan pedesaan. Identifikasi terhadap petani responden dilakukan melalui pengukuran terhadap umur, 
jenis kelamin, tingkat pendidikan terakhir, jumlah tanggungan keluarga, dan pekerjaan pokok dari cabang usahatani yang dilaksanakan sebagai sumber pencaharian hidupnya.

Keadaan umur responden berpengaruh terhadap kemampuan fisik, cara berpikir, dan respon terhadap berbagai program pembangunan pedesaan yang dilaksanakan pemerintah di desa sasaran penelitian (Sumardjo, Saharuddin,2004). Sebaran petani responden berdasarkan usia produktif (15 - 55 tahun ) dan atau non produktif $(<15$ tahun dan $>55$ tahun), disajikan pada Tabel 1 .

Tabel 1. Sebaran Usia Petani Responden pada Lokasi Penelitian

\begin{tabular}{cccc}
\hline No & Usia Petani Responden (tahun) & Jumlah & Persentase \\
\hline 1. & $<15$ tahun (usia non produktif) & - & 0,00 \\
2. & $15-55$ tahun (usia produktif) & 48 & 96,00 \\
3. & $>55$ tahun (usia non produktif) & 2 & 4,00 \\
\hline & Jumlah & 50 & 100,00 \\
\hline
\end{tabular}

Tabel 1 menunjukkan bahwa 96 persen petani responden berada pada usia produktif, artinya memiliki kemampuan fisik, cara berpikir, dan respon yang baik terhadap program pembangunan pedesaan. Selebihnya 4 persen sebaran usia petani responden berada pada usia non produktif. Berdasarkan hal tersebut dapat diketahui bahwa responden dalam pelaksanaan studi/kajian ini cukup partisipatif dalam memberikan jawaban dan peniliaian tingkat partisipasi petani terhadap pelaksanaan pembangunan pedesaan.

Faktor jenis kelamin petani responden merupakan salah satu parameter untuk melihat seberapa besar keterlibatan kaum laki-laki dan perempuan serta keikutsertaan mereka dalam pelaksanaan pembangunan pedesaan. Berdasarkan jenis kelamin responden dapat diperoleh gambaran bahwa keterlibatan responden sampel yang berjenis kelamin laki-laki lebih dominan dibanding perempuan dalam pelaksanaan pembangunan pedesaan, disajikan pada Tabel 2.

Tabel 2. Keadaan Jenis Kelamin Petani Responden pada Lokasi Penelitian

\begin{tabular}{cllcc}
\hline No & & Jenis Kelamin & Jumlah & Persentase \\
\hline 1. & Laki-laki & & 41 & 82,00 \\
2. & Perempuan & & 9 & 18,00 \\
\hline & & Jumlah & 50 & 100,00 \\
\hline
\end{tabular}

Dengan memperhatikan perimbangan kaum laki-laki dan perempuan yang terlibat dan berpartisipasi dalam pembangunan pedesaan, maka dapat dikatakan kontribusi dan peranan kaum laki-laki dan kaum perempuan cukup representative terwakili dalam penelitian ini, dengan tidak mengabaikan aspek kesetaraan gender (gender sensity) dalam pembangunan.

Tingkat pendidikan petani responden merupakan salah satu faktor yang cukup berpengaruh terhadap pelaksanaan pembangunan pedesaan. Hal ini dikarenakan tingkat pendidikan responden yang layak cenderung memberi respon yang baik serta memberi motivasi yang kuat bagi seseorang untuk berpartisipasi aktif dalam pelaksanaan pembangunan pedesaan, disajikan pada Tabel 3. 
Tabel 3. Keadaan Tingkat Pendidikan Petani Responden pada Lokasi Penelitian

\begin{tabular}{clcc}
\hline No & \multicolumn{1}{c}{ Tingkat Pendidikan } & Jumlah & Persentase \\
\hline 1. & Tamat SD & 3 & 6,00 \\
2. & SLTP & 14 & 28,00 \\
3. & SLTA & 31 & 62,00 \\
4. & SARMUD/D.III & 2 & 4,00 \\
& & & 100,00 \\
\hline & Jumlah & 50 & \\
\hline
\end{tabular}

Tabel 3 di atas menunjukkan bahwa sebanyak 33 orang petani responden atau sekitar 66 persen dikategorikan berada di atas standar tingkat pendidikan dasar (masa pendidikan 9 tahun) serta selebihnya sebanyak 14 orang atau 28 persen memiliki standar pendidikan dasar dan 3 orang atau 6 persen masih dibawah standar tingkat pendidikan dasar. Tingkat pendidikan yang dimiliki petani responden secara representatif cukup memadai untuk menyerap dan memahami kebutuhan pembangunan pedesaan yang telah dilaksanakan dalam lokasi penelitian.

Besar kecilnya jumlah tanggungan keluarga petani responden juga sangat berpengaruh terhadap motivasi dan keterlibatan petani dalam pelaksanaan pembangunan pedesaan (Syaukat, 2004). Faktor jumlah tanggungan keluarga dapat memberi kecenderungan kepada petani responden untuk berusaha mencari nafkah hidup secara maksimal. Untuk lebih jelasnya mengenai jumlah tanggungan keluarga petani responden dapat dilihat pada Tabel 4.

Tabel 4. Keadaan Jumlah Tanggungan Keluarga Petani Responden pada Lokasi Penelitian

\begin{tabular}{clcc}
\hline No & \multicolumn{1}{c}{ Jumlah Tanggungan Keluarga } & Jumlah & Persentase \\
\hline 1. & 1- 2 orang & 9 & 18,00 \\
2. & 3- 4 orang & 21 & 42,00 \\
3. & 5- 6 orang & 20 & 40,00 \\
4. & Diatas 6 orang & - & 0,00 \\
\hline \multicolumn{2}{r}{ Jumlah } & 50 & 100,00 \\
\hline
\end{tabular}

Besarnya jumlah tanggungan keluarga petani responden memberi indikasi bahwa peluang alokasi waktu dan frekuensi petani responden untuk terlibat dan berpartisipasi dalam kegiatan pembangunan pedesaan, dan umumnya petani responden yang mempunyai jumlah tanggungan keluarga besar yang lebih dominant terlibat dan cukup berperan dalam pelaksanaan pembangunan pedesaan.

Jenis pekerjaan usahatani yang menjadi pekerjaan pokok petani responden adalah faktor yang cukup berpengaruh terhadap keterlibatan dan wujud partisipasi petani responden dalam pembangunan pedesaan. Karakteristik potensi wilayah pedesaan dan aktivitas jenis kegiatan usahatani cukup bervariasi pada lokasi penelitian. Jenis pekerjaan petani responden bervariasi berdasarkan cabang usahatani yang dilaksanakan sehari-hari meliputi usahatani padi sawah (petani-padi), usahatani kakao (petani kakao), usahatani ternak ayam-sapi (peternak), dan usahatani kolam ikan air tawar (petani-ikan). Untuk lebih jelasnya mengenai jenis pekerjaan pokok petani responden dapat dilihat pada Tabel 5, berikut ini. 
Tabel 5. Jenis Pekerjaan Pokok Petani Responden pada Lokasi Penelitian

\begin{tabular}{clcc}
\hline No & Jenis Pekerjaan Pokok Usahatani & Jumlah & Persentase \\
\hline 1. & Usahatani Padi & 41 & 82,00 \\
2. & Usahatani Kakao & 3 & 6,00 \\
3. & Usahatani Ternak Ayam-Sapi & 5 & 10,00 \\
4. & Usahatani Kolam Ikan air tawar & 1 & 2,00 \\
\hline \multicolumn{2}{c}{ Jumlah } & 50 & 100,00 \\
\hline
\end{tabular}

Berdasarkan Tabel 5, terlihat bahwa jenis pekerjaan pokok usahatani responden sebagian besar berstatus petani padi-sawah yakni sebanyak 82 persen, dan selebihnya petani kakao sebanyak 6 persen, peternak sebanyak 10 persen, dan petani ikan sebanyak 2 persen. Jenis usahatani petani responden sangat penting untuk mengetahui bentuk partisipasi dan perwujudan partisipasi petani dalam pembangunan pedesaan, karena menyangkut aktivitas rutin yang harus dilakukan oleh petani dan keluarganya dalam memenuhi kebutuhan hidup keluarganya. Disamping itu jenis usahatani dapat dijadikan gambaran karakteristik potensi pertanian daerah di wilayah Kabupaten Konawe.

\section{Partisipasi Petani Responden dalam Pengembangan Sarana dan Prasarana Pedesaan}

Komponen partisipasi petani dalam pengembangan sarana dan prasarana pedesaan dilihat dari aspek keterlibatan petani dalam perencanaan pengembangan sarana dan prasarana pedesaan, pembangunan jalan desa, pembangunan jalan usahatani, perbaikan sarana dan prasarana desa, perbaikan jaringan irigasi desa, pembangunan jembatan dan rumah ibadah, perbaikan saluran drainase desa, pengelolaan karang gizi keluarga pedesaan, dan penanggulangan kemiskinan dipedesaan pada lokasi penelitian.

Hasil pengumpulan data lapangan dapat diketahui bahwa kategori partisipasi petani sangat bervariasi dalam pengembangan sarana dan prasarana pedesaan di wilayah Kabupaten Konawe. Kondisi objektif menunjukkan bahwa secara kualitatif tingkat partisipasi petani masih rendah keterlibatannya dalam pengembangan sarana dan prasarana pedesaan karena masih didominasi oleh kalangan elit desa yang sering terlibat dalam panitia pembangunan desa sehingga masyarakat petani masih kurang diberi kesempatan untuk terlibat secara penuh. Untuk lebih jelasnya mengenai partisipasi petani dalam pengembangan sarana dan prasarana pedesaan dapat dilihat pada Tabel 6, berikut ini.

Tabel 6. Kategori Partisipasi Petani Responden Dalam Pengembangan Sarana dan Prasarana Pedesaan pada Lokasi Penelitian

\begin{tabular}{clcc}
\hline No & \multicolumn{1}{c}{ Kategori Partisipasi Petani } & Jumlah Responden & Persentase \\
\hline 1. & Partisipasi Penuh ( PP) & 8 & 16,00 \\
2. & Partisipasi Setengah/Kadang (PS) & 36 & 72,00 \\
3. & Partisipasi Kurang (PK) & 6 & 12,00 \\
\hline & Jumlah & 50 & 100,00 \\
\hline
\end{tabular}

Dari Tabel 6, dapat diketahui bahwa partisipasi petani dalam pengembangan sarana dan prasarana pedesaan masih 16 persen yang terkategori partisipasi penuh sesuai skor komponen partisipasi yang ditentukan, selebihnya partisipasi petani yang terkategori partisipasi setengah atau kadang saja 72 persen, dan kategori partisipasi kurang sebanyak 12 persen petani responden. Nampak terlihat bahwa perwujudan partisipasi petani dalam 
pengembangan sarana dan prasarana pedesaan yang dilaksanakan masih dominan berada pada batasan kategori partisipasi sedang atau kadang-kadang, hal tersebut disebabkan karena kesempatan petani untuk terlibat masih terhambat dengan aturan system sosial kemasyarakatan yang penekanannya berasal dari kalangan elit desa yang menginginkan bentuk kebersamaan partisipasi yang terikat dalam tatanan yang sifatnya formal.

Di sisi lain petani mempunyai persepsi bahwa keterlibatan mereka dalam pengembangan sarana dan prasarana pedesaan sesuai dengan kerelaan mereka untuk berpartisipasi dan tidak perlu selalu diatur dalam tatanan formal, karena apa yang dikerjakan oleh mereka adalah kebutuhan yang sifatnya mendasar dalam menunjang aktivitas pencaharian nafkah hidup keluarganya, tanpa insentif atau paksaan yang sifatnya formal.

\section{Partisipasi Petani Responden Dalam Penguatan Kelembagaan Sosial Ekonomi Pedesaan}

Komponen partisipasi petani dalam penguatan kelembagaan sosial ekonomi pedesaan dilihat dari aspek keterlibatan peran petani dalam keanggotaan kelompoktani, keterlibatan dalam pertemuan/sosialisasi kelembagaan, kegiatan gotong royong dan bakti sosial kemasyarakatan, pengurusan organisasi petani pengguna pengairan dan air (P3A), penanganan lumbung pangan desa, pengurusan organisasi koperasi unit desa (KUD) dan peran petani dalam organisasi sosial lainnya (LPM/LKMD) dipedesaan pada lokasi penelitian.

Hasil pengumpulan data lapangan dapat diketahui bahwa kategori partisipasi petani dalam penguatan kelembagaan sosial ekonomi pedesaan di wilayah Kabupaten Konawe menunjukkan bahwa tingkat partisipasi petani masih rendah keterlibatannya dalam penguatan kelembagaan sosial ekonomi pedesaan karena masih rendahnya kemampuan petani untuk mengelola kelembagaan sosial ekonomi pedesaan sehingga kebanyakan petani masih kurang berperan dalam kepengurusan organisasi kemasyarakatan di desa. Untuk lebih jelasnya mengenai partisipasi petani dalam penguatan kelembagaan sosial ekonomi pedesaan dapat dilihat pada Tabel 7, berikut ini.

Tabel 7. Kategori Partisipasi Petani Responden Dalam Penguatan Kelembagaan Sosial Ekonomi Pedesaan pada Lokasi Penelitian

\begin{tabular}{clcc}
\hline No & \multicolumn{1}{c}{ Kategori Partisipasi Petani } & Jumlah & Persentase \\
\hline 1. & Partisipasi Penuh ( PP) & 3 & 6,00 \\
2. & Partisipasi Sedang/Kadang (PS) & 42 & 84,00 \\
3. & Partisipasi Kurang (PK) & 5 & 10,00 \\
\hline & $\quad$ Jumlah & 50 & 100,00 \\
\hline
\end{tabular}

Dari Tabel 7, dapat diketahui bahwa partisipasi petani dalam penguatan kelembagaan sosial ekonomi pedesaan masih 6 persen yang terkategori partisipasi penuh sesuai skor komponen partisipasi yang ditentukan, selebihnya partisipasi petani yang terkategori partisipasi sedang atau kadang saja 84 persen, dan kategori partisipasi kurang sebanyak 10 persen petani responden. Nampak terlihat bahwa perwujudan partisipasi petani dalam penguatan kelembagaan sosial ekonomi pedesaan yang dilaksanakan masih dominan berada pada batasan kategori partisipasi sedang atau kadang-kadang. Hal tersebut disebabkan karena kesempatan petani untuk terlibat masih dibatasi dengan kemampuan SDM yang dimiliki petani dalam pengelolaan organisasi sosial kemasyarakatan yang penekanannya bukan pada usahatani yang mereka kerjakan secara rutinitas dalam masyarakat pedesaan. Keterbatasan 
kemampuan pengetahuan dan wawasan berorganisasi yang dimiliki sebagian besar oleh petani sangat mempengaruhi posisi dan peran petani untuk terlibat dalam kepengurusan organisasi kelembagaan sosial ekonomi pedesaan.

\section{Partisipasi Petani Responden Dalam Peningkatan Produksi Pertanian Pedesaan}

Komponen partisipasi petani dalam peningkatan produksi pertanian pedesaan dilihat dari aspek keterlibatan peran petani dalam pemanfatan teknologi produksi, keterlibatan dalam penanganan pasca panen, kegiatan penerapan panca usahatani, frekuansi mengikuti penyuluhan pertanian, kegiatan perencanaan partisipatif desa atau participatory rural apraisal (PRA), dalam hal rencana penggunaan benih unggul, peran dan aksi dalam pengendalian hama secara terpadu (PHT), penyiapan sarana produksi pertanian (saprotan), serta pemanfaatan lahan tidur dipedesaan pada lokasi penelitian.

Hasil pengumpulan data lapangan dapat diketahui bahwa kategori partisipasi petani dalam peningkatan produksi pertanian pedesaan di wilayah Kabupaten Konawe menunjukkan sebagian besar pada tingkat partisipasi sedang, sehingga petani masih belum maksimal keterlibatannya dalam peningkatan produksi pertanian pedesaan yang sesuai dengan potensi produktifitas komoditi pertanian di Kabupaten Konawe, karena masalah kemampuan teknis, ekonomi dan sosial petani masih rendah serta terbatasnya pengetahuan dan keterampilan manajerial yang dimiliki untuk mengelola usahataninya. Untuk lebih jelasnya mengenai partisipasi petani dalam peningkatan produksi pertanian pedesaan, disajikan pada Tabel 8 .

Tabel 8. Kategori Partisipasi Petani Responden dalam Peningkatan Produksi Pertanian Pedesaan pada Lokasi Penelitian

\begin{tabular}{clcc}
\hline No & \multicolumn{1}{c}{ Kategori Partisipasi Petani } & Jumlah Responden & Persentase \\
\hline 1. & Partisipasi Penuh ( PP) & 5 & 10,00 \\
2. & Partisipasi Sedang/Kadang (PS) & 33 & 66,00 \\
3. & Partisipasi Kurang (PK) & 12 & 24,00 \\
\hline & Jumlah & 50 & 100,00 \\
\hline
\end{tabular}

Dari Tabel 8, dapat diketahui bahwa partisipasi petani dalam peningkatan produksi pertanian pedesaan masih 10 persen yang terkategori partisipasi penuh, selebihnya partisipasi petani terkategori partisipasi sedang atau kadang saja 66 persen, dan kategori partisipasi kurang sebanyak 24 persen dalam aktivitas petani responden dibidang pertanian pedesaan. Indikasi tersebut menunjukkan bahwa petani berpartisipasi dalam peningkatan produksi pertanian pedesaan masih belum berdasarkan kesadaran sendiri, tetapi lebih banyak didasarkan atas dorongan orang lain atau dimobilisasi oleh teman dan rekan petani lainnya, terutama pengaruh dari penyuluh pertanian lapangan (PPL) yang sifatnya berupa instruktif.

\section{Hasil Studi Partisipasi Petani dalam Pembangunan Pedesaan}

Hasil studi partisipasi petani dalam pembangunan pedesaan di wilayah Kabupaten Konawe yang diukur melalui pendekatan model partisipasi penuh, sedang atau kadang, dan partisipasi kurang terhadap petani responden sampel, memberi gambaran secara komperehensif tentang seberapa jelas bentuk dan wujud tingkat 
partisipasi petani dalam pembangunan pedesaan. Wujud partisipasi adalah kesadaran mengenai kontribusi yang dapat diberikan oleh seseorang atau pihak-pihak lain dalam suatu kegiatan pembangunan. Dengan kata lain, partisipasi seyogyanya dimunculkan secara nyata dan berkelanjutan (suistainable) dalam masyarakat pedesaan, oleh karena itu petani anggota kelompoktani yang menjadi target group atau sasaran kelompok masyarakat pedesaan sebagai pengambil manfaat/keuntungan dalam berbagai kegiatan pembangunan di pedesaan mutlak harus terlibat.

Analisis data lapangan tentang tingkat partisipasi petani terhadap beberapa komponen pembangunan pedesaan memberi kecenderungan terhadap rata-rata kesadaran petani masih pada tingkat partisipasi setengah/sedang sebanyak 72 persen, dan telah mencapai tingkat partisipasi tinggi sebanyak 10,66 persen. Selebihnya sebanyak 17,34 persen petani dinyatakan kurang berpartisipasi dalam pelaksanaan pembangunan pedesaan di wilayah Kabupaten Konawe.

Beberapa indikator yang nampak berpengaruh terhadap rendahnya tingkat partisipasi petani dalam kegiatan pembangunan pedesaan lebih banyak disebabkan oleh kurangnya kesempatan yang diberikan kepada masyarakat petani dipedesaan, belum tepatnya sasaran program pemberdayaan ditingkat masyarakat petani, serta masalah keadilan (justice) yang diperoleh masyarakat petani dalam pelaksanaan aktivitas pembangunan pedesaan.

\section{Kesimpulan}

Bentuk partisipasi petani dalam pembangunan pedesaan di wilayah Kabupaten Konawe, dilakukan dengan tiga pendekatan partisipasi yaitu : partisipasi petani dalam pengembangan sarana dan prasarana pedesaan, patisipasi petani dalam penguatan kelembagaan sosial ekonomi pedesaan, dan partisipasi petani dalam peningkatan produksi pertanian pedesaan. Hasil studi partisipasi petani dalam pembangunan pedesaan yang diukur dari kesadaran dan keterlibatannya untuk berpartisipasi secara sadar menunjukkan bahwa rata-rata partisipasi petani sebagian besar masih terkategori pada tingkat partisipasi sedang (PS) yakni sebanyak 72 persen, dan selebihnya berada pada tingkat partisipasi penuh (PP) sebanyak 10,66 persen, serta tingkat partisipasi kurang (PK) sebanyak 17,34 persen. Kondisi tersebut cenderung disebabkan oleh kesempatan petani untuk terlibat dalam berpartisipasi masih terhambat dengan aturan system sosial yang penekanannya berasal dari kalangan elit desa, disamping itu keterbatasan kemampuan SDM yang dimiliki petani, serta dorongan partisipasi masih banyak dipengaruhi oleh mobilisasi sosial masyarakat dan penyuluh pertanian lapangan (PPL) di pedesaan.

Hambatan petani untuk melakukan partisipasi penuh secara sadar belum maksimal dapat diwujudkan secara nyata dalam pembangunan pedesaan, akibat kekeliruan dalam mempersepsikan tentang peluang partisipasi, dengan sistem mobilisasi sosial yang masih kental dalam lingkungan masyarakat pedesaan, serta adanya ketergantungan petani terhadap program pemberdayaan masyarakat yang dialokasikan oleh Pemerintah Daerah dan Pusat. Fenomena ini terlihat dari analisis persepsi dan pernyataan petani responden dalam memaknai partisipasi dan menyikapi pelaksanaan pembangunan didesanya serta keterlibatannya dalam melaksanakan kegiatan pembangunan di pedesaan, dengan bentuk-bentuk implementasi pembangunan yang belum sesuai dengan kebutuhan masyarakat petani di pedesaan.

Tingkat partisipasi petani akan muncul dan dapat terwujud secara nyata, apabila didukung adanya kesempatan, kemauan, dan kemampuan untuk berperan dan terlibat secara sadar dalam pelaksanaan pembangunan pedesaan, yang direpresentasikan dalam bidang pertanian sebagai sumber mata pencaharian utama bagi kesejahteraan hidup 
masyarakat pedesaan, baru mencapai tingkat partisipasi penuh (PP) sebesar 10,66 persen. Artinya bentuk dan wujud partisipasi masyarakat secara nyata masih sangat rendah untuk memanfaatkan peluang berpartisipasi aktif dan nyata dalam program pembangunan pertanian pedesaan.

\section{Daftar Pustaka}

Adi.R,I. 2003. Pemberdayaan, Pengembangan Masyarakat dan Intervensi Komunitas. Jakarta: Fakultas Ekonomi Universitas Indonesia.

Badan Perencanaan Pembangunan Nasional. 2003. Program Pemberdayaan Masyarakat. Jakarta: Bappenas.

Biro Pusat Statistik. 2005. Konawe Dalam Angka. BPS Kab. Konawe. Unaaha

Departemen Pertanian. 1999. Pedoman Umum Perencanaan Partisipasi Penyuluhan Pertanian. Jakarta: Pusat Pembinaan Penyuluhan. Deptan.

Lipton, M. 1980. Metodologi Studi Pedesaan Di Negara-Negara Berkembang. Jakarta: Yayasan Ilmu Ilmu Sosial.

Syahyuti, 2006. 30 Konsep Penting dalam Pembangunan Pedesaan dan Pertanian. Jakarta: PT Bina Rena Pariwara.

Slamet,M. 2003. Membentuk Pola Perilaku Manusia Pembangunan. Bogor: IPB Press.

Sumardjo, Saharuddin, 2004. Modul Metode - Metode Partisipatif Dalam Pengembangan Masyarakat. MPM. SPs- IPB. Bogor

Syaukat,Y, 2004. Modul Pengembangan Ekonomi Lokal. MPM . SPs- IPB. Bogor

Tonny.F, Utomo. BS, 2004. Pengembangan Kelembagaan dan Modal Sosial. MPM SPs- IPB. Bogor. 